\title{
First record of Thecacineta calix (Ciliophora: Suctoria) on harpacticoid copepod from Aegean Sea, Turkey
}

\author{
FURKAN DURUCAN \\ Işı1klar Caddesi No. 16, TR-07100 Antalya, Turkey \\ Corresponding author: email: f_durucan@hotmail.com
}

Keywords Suctorians, epibiosis, environment, host specificity, diagnosis

Abstract The present study report a marine suctorian species Thecacineta calix (Schroder, 1907) on harpacticoid copepod collected from Fethiye (Muğla), Aegean Sea, Turkey. This is the first record of this suctorian ciliates from Turkey. It is also first record of this species from Aegean Sea.

Pierwsze stwierdzenie Thecacineta calix (Ciliophora: Suctoria) widłonoga z rzędu Harpacticoida z Morza Egejskiego, Turcja

Słowa kluczowe sysydlaczki, epibioza, środowisko, wybiórczość gospodarza, diagnoza

Streszczenie W artykule zaprezentowano pierwsze stwierdzenie w Turcji i na Morzu Egejskim morskiego sysydlaczka Thecacineta calix (Schroder, 1907) stwierdzonego w Fethiye (Muğla), Morze Egejskie, Turcja.

\section{Introduction}

Suctorian ciliates can be found in all types of water bodies on a wide diversity of hosts and substrates. They inhabit both anorganic and organic material, plants and aninals and feed microalgae and other ciliates. Several suctorian ciliates are common epibionts of benthic marine and interstitial invertebrates. Marine and fresh water mites have been identified as hosts of suctorian ciliates which may be commensals, ecto - or endoparasites. They are common epibionts on marine and freshwater invertebrates such as copepods, cladocerans, nematodes, kinorhynchs, halacarid and hydrachnid mites (Chatterjee, Nanajkar, Dovgal, Sergeeva, Bhave, 2019; Durucan, Boyac1, 2016; Durucan, Artüz, Dovgal, 2019). In Turkey, the first taxonomic study on marine suctorians was done by Durucan and Boyac1 (2019) who reported Praethecacineta halacari (Schulz, 1933) on Copidognathus venustus Bartsch, 1977 from Levantine Sea (Antalya). After that, Durucan et al. (2019) reported Paracineta irregularis Dons, 1928 on Rhombognathus sp. from Sea of Marmara. 
In the present study, specimens of Thecacineta calix were observed on a marine harpacticoid copepod as epibionts for the first time in Turkey. This record also new for Aegean Sea.

\section{Material and Methods}

The present study is based on material collected by the author whilst studying halacarids from Fethiye, Muğla (September, 2019) $\left(36.602517^{\circ} \mathrm{N}, 29.030953^{\circ} \mathrm{E}\right)$ (Figure 1). Sediment samples were collected by using SCUBA at locality. After that sediment samples were sieved in $100 \mu \mathrm{m}$ in the laboratory under a binocular microscope (Nikon SMZ 10). Drawings were made using a camera lucida microscope (Nikon Eclipse E400). The light microscopy photographs were taken with camera phone (Honor Play 8A). The ciliated harpacticoid copepod specimen mounted in Hoyer's medium and kept in the author's personal collection in Antalya.

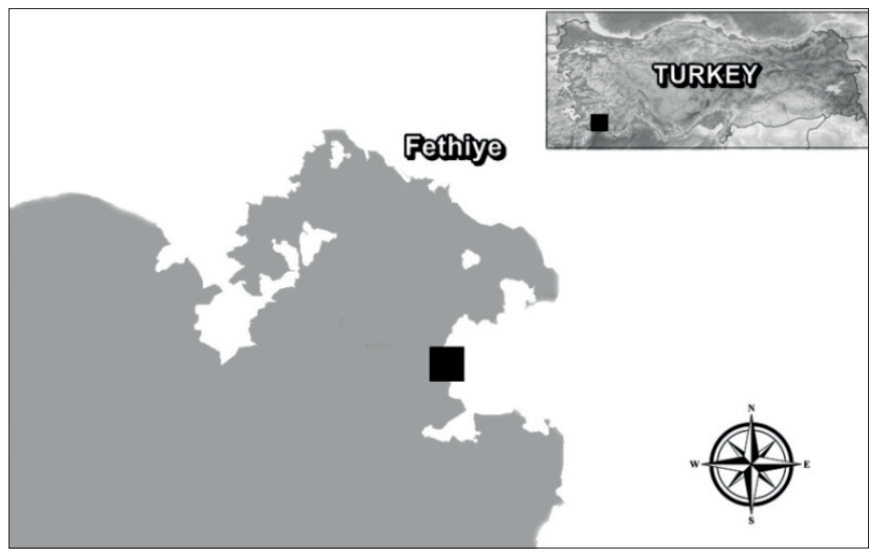

Figure 1. Map of the study area (black square) showing the sampling station (Fethiye, Muğla)

\section{Results and Discussion}

\section{Systematics}

Class Suctorea Claparede \& Lachmann, 1859

Subclass Vermigenia Jankowski, 1978

Order Spelaeophryida Jankowski, 1978

Family Thecacinetidae Matthes, 1956

Genus Thecacineta Collin, 1909

Thecacineta calix (Schroder, 1907) (Figure 2)

\section{Material examined}

Five suctorian ciliates identified as Thecacineta calix have been observed on the cuticle of the harpacticoid copepod collected from medium coarse sand, at a depth of $10 \mathrm{~m}$, in Fethiye, Muğla (September, 2019) $\left(36.602517^{\circ} \mathrm{N}, 29.030953^{\circ} \mathrm{E}\right)$ (Figure 1). Coll. F. Durucan. 


\section{Diagnosis}

Marine loricate suctorian. Whole lorica cuticle with covered by annular ridges (13-16). Length of lorica 100-110 $\mu \mathrm{m}$; width of lorica 50-60 $\mu \mathrm{m}$. Macronucleus large, oviform, located at the bottom of the cell body (Dovgal, Chatterjee, Ingole, 2008) (Figure 2).

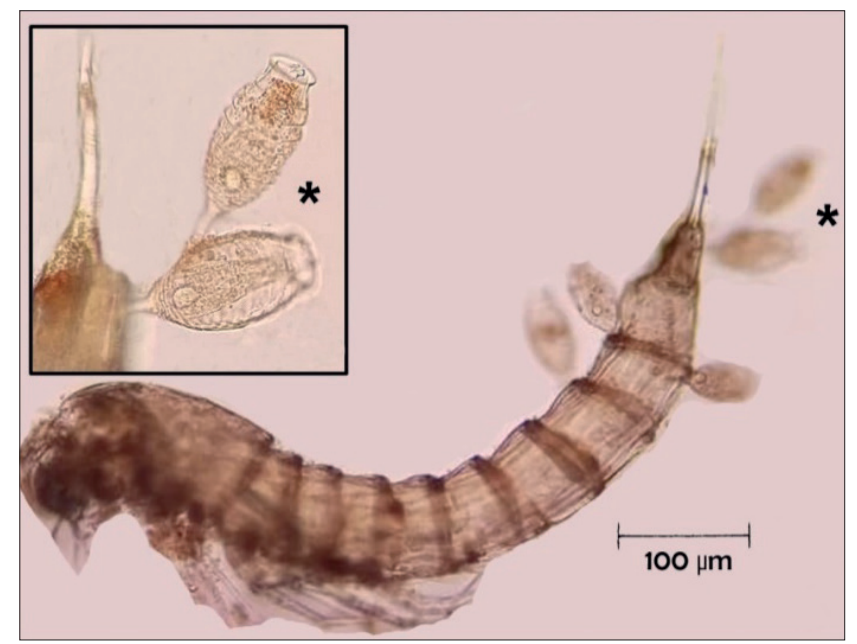

Figure 2. Posterior part of harpacticoid copeod with Thecacineta calix marked with an asterisk

\section{Distribution and host specificity}

In this study, only a ciliated harpacticoid copepod has been found from the sampling area while studying on halacarid mites along Fethiye coast. Thecacineta calix (Schroder, 1907) was described by Schroder (1907) from a marine nematodes from Kerguelen Islands, Antarctica. The species has distributed worldwide (Chatterjee et al., 2019). However, the species was recorded only from the Adriatic Sea (Rovinj and Trieste) in the Mediterranean basin (Chatterjee et al., 2019).

Including this study, total number of known marine suctorian ciliate is reach 2 to 3 in Turkey after reporting Paracineta irregularis Dons, 1928 and Praethecacineta halacari (Schulz, 1933) (Durucan, Boyac1, 2019; Durucan et. al., 2019).

\section{Acknowledgements}

I would like to thank due to Isparta University of Applied Sciences, Eğirdir Fisheries Faculty, Biology, Ecology and Limnology laboratory (Isparta, Turkey) for providing laboratory facilities. I am also very thankful to anonymous reviewers for their constructive comments on the manuscript. 


\section{References}

Chatterjee, T., Nanajkar, M., Dovgal, I., Sergeeva, N., Bhave, S. (2019). New records of epibiont Thecacineta calix (Ciliophora: Suctorea) from the Caspian Sea and Angriya Bank, Arabian Sea. Cahiers de Biologie Marine, 60, 445-451.

Dovgal, I.V., Chatterjee, T., Ingole, B. (2008). An overview of Suctorian ciliates (Ciliophora, Suctorea) as epibionts of halacarid mites (Acari: Halacaridae). Zootaxa, 1810, 60-68.

Durucan, F., Boyac1, Y.Ö. (2016). First Record of the Ciliate Praethecacineta halacari (Ciliophora: Suctorea) Epibiont on Copidognathus Halacarid Mite from Portugal. Süleyman Demirel Üniversitesi Ĕgirdir Su Ürünleri Fakültesi Dergisi, 12 (2), 97-100.

Durucan, F., Artüz, M.L., Dovgal, I.V. (2019). The first record of Paracineta irregularis (Ciliophora, Suctorea) as epibiont on Rhombognathus halacarid mite (Acari, Halacaridae) from the Sea of Marmara, Turkey. Protistology, 13 (2), 67-70.

Durucan, F., Boyac1, Y.Ö. (2019). First record of Praethecacineta halacari (Suctorea: Ciliophora) from Antalya, Turkey. Acta Aquatica Turcica, 15 (2), 135-138. DOI: 10.22392/actaquatr.577448.

Cite as: Durucan, F. (2019). First record of Thecacineta calix (Ciliophora: Suctoria) on harpacticoid copepod from Aegean Sea, Turkey. Acta Biologica, 26, 31-34. DOI: 10.18276/ab.2019.26-03. 